\title{
高温時の酸化皮膜挙動に着目したクロム銅合金の 拡散接合性改善
}

\section{塚 本 雅 章}

兵庫県立大学大学院工学研究科材料·放射光工学専攻

J. Japan Inst. Met. Mater. Vol. 80, No. 3 (2016), pp. 206-212

(C) 2016 The Japan Institute of Metals and Materials

\section{Improvement of Diffusion Bondability on Chromium-Copper Alloy by Behavior of Oxide Layer at High Temperature}

\author{
Masaaki Tsukamoto \\ Department of Material Science and Synchrotron Radiation Engineering, Graduate School of Engineering, University of \\ Hyogo, Himeji 671-2201
}

Diffusion bonding method of chromium-copper alloy having a stable oxide layer was developed to improve tensile strength with low deformation of a specimen. In a manner of breaking the oxide layer by means of pressing, the tensile strengths were not well obtained and the specimens were moreover deformed. As the reason, contained chromiums were moved onto the bonding surfaces from bulk and subsequent oxidized with heating even in vacuum. It could be suppressed when the roughness of bonding surfaces was significantly smoothed. The specimens with smoothing surfaces were diffusion-bonded at $1073 \sim 1173 \mathrm{~K}$ for $3.6 \mathrm{ks}$ without pressing. All the bonded specimens were fractured at the base metal. The bonded interface in the specimen fabricated at $1173 \mathrm{~K}$ could not specified on the SEM image. Also, the diffusion bonding was carried out with inserting a nickel film between the bonding surfaces in order to identify mutual diffusion. Nickel was theoretically diffused into chromium-copper alloys. It proved that metallic bonds were achieved between the bonded surfaces. However, a chromium oxide layer are easy to be generated at room temperature in atmosphere. The oxide layers had been already formed around chromium precipitations existing on the bonding surfaces before diffusion bonding. It was found that these cohered with heating, which enable the specimens to increase the bonded area. On the other hand, grain boundary migration over the bonded interface was not partly occurred in the specimen fabricated at $1073 \mathrm{~K}$. An oxide and a void have been known to prevent the migration. In the case of diffusion bonding at $1173 \mathrm{~K}$, the bonded interface disappeared by the migration in spite of residual oxide aggregations. Therefore, the void would be responsible for delaying the migration. [doi:10.2320/jinstmet.JBW201510]

(Received October 20, 2015; Accepted November 30, 2015; Published January 29, 2016)

Keywords: chromium-copper alloy, diffusion bonding, chromium oxide layer, temperature, surface roughness, aggregation, low deformation

\section{1. 緒言}

ヒートシンクのように優れた熱伝導性や導電性が要求され る部分には無酸素銅が使用されることが一般的となったが， 材料強度が乏しいとの理由から，近年では無酸素銅をクロム 銅合金へと置き換えるケースも増えてきた．これに伴い，こ れまで無酸素銅に対して確立されてきた各種加工法をクロム 銅合金に同様に適用しても通用しない場合があり，その一例 に拡散接合も該当する.

クロム銅合金は熱を集中させることが難しく，溶接では割 れやブローホールの問題が生じやすい1). そのため, 固相接 合法を用いる上では, 継手部の信頼性が高く, 多くの特長を 有している拡散接合法の採用が有意だと思われる．無酸素銅 をはじめとする添加元素を含まない純銅であれば，酸化皮膜 は銅酸化物のみで形成される，銅の酸化に対する標準反応ギ ブズエネルギー $\Delta G^{\ominus}$ は，同温において他金属よりも高い值 を示す，換言すれば，各種酸化物の中でも銅酸化物は生成し
にくく，逆に高温および低酸素分圧下では分解反応が起こり やすくなるということである，純銅の場合は，雾囲気制御し た環境内で拡散接合を行うことにより接合面における清浄化 の問題は解決できるため, 継手強度は面同士の密着面積にほ ぼ比例する関係にある2,3)。しかし，クロムの添加により析 出強化を図っているクロム銅合金には，クロム酸化物を主と する酸化皮膜が生成されている．クロムは酸素との親和力が 強く, クロムが酸素と反応してクロム酸化物になる自発的反 応を抑制できる䨌囲気を作り出すことは極めて困難である.

前述のような酸化皮膜に覆われる金属では, 対象物に荷重 を負荷することで接合面上の凹凸部を変形させて酸化皮膜を 破砕分散し, 新生面を押し出す方法が主流である.クロム銅 合金に関しても, 破砕分散法を用いる際の接合温度, 接合圧 力および接合時間などの適正条件を調べ，母材強度に近接す る継手強度が得られたことをこれまでに報告した4).その反 面, 温度を上昇させるとともにクロム銅合金が急激に軟化傾 向を示し, 加圧によって試料自体の外観が大きく損なわれる ことを併せて報告した。これは，既に目標とする形状に加工 
された対象物に対しては拡散接合ができないことを意味して いる.さらに加えて言うと, クロム銅合金では内部流路を設 けたような中空構造体が製作できないということになる．実 用製品に対応するためには，対象物に負荷をかけることなく 酸化皮膜を除去し，接合面間の金属結合を達成させる方法を 考案しなければならない。

クロム酸化皮膜の生成は進行が速く, 接合直前に化学研磨 などの清浄化を施しても接合面が一度大気に触れると効果が 薄れてしまう。 大橋らは, 接合温度 $1373 \mathrm{~K}$ で拡散接合した オーステナイトステンレス鋼(SUS304)の引張試験を行い, その破面からクロム, マンガンおよびシリコンを含んだ介在 物を検出し，これを酸化皮膜が凝集したものであると述べて いる5). $1373 \mathrm{~K}$ ではクロム銅合金は溶融してしまうが，ク ロム酸化皮膜が凝集する温度を明確にし, その挙動が融点以 下で起こるのであれば相互拡散が可能になるはずである.

本研究では, 拡散接合に従来必要とされてきた圧力負荷を 対象物に対して一切行わず，工業的に作り出せる酸素分圧下 (真空度)内でクロム酸化皮膜が高温で示す挙動に着目し, こ れを活用してクロム銅合金の拡散接合性を改善することを目 的とした.

\section{2. 実 験 方 法}

供試材には，市販のクロム銅合金丸棒を使用した．添加さ れているクロム量は 1 mass\%であり，時効処理を行い析出 硬化された材料である. 旋盤加工によりサイズを $\phi 15 \mathrm{~mm} \times$ $30 \mathrm{~mm}$ とし, 拡散接合の対象となる面は, エメリ一研磨お よびアルミナ粉末 (粒径 $1 \mu \mathrm{m}$ )を用いたバフ研磨を施して面 粗度が $R_{\mathrm{a}}: 0.02 \mu \mathrm{m}$ になるように仕上げた．付着した砥粒 やアルミナ粉末を除去するためにリン酸と過酸化水素水の混 合液を用いて室温で $30 \mathrm{~s}$ の化学研磨を行った後, 拡散接合 に供した。

真空排気時に試料が動かないようにカーボン製の治具で軽 く固定し，炉内の真空度が $4 \times 10^{-3} \mathrm{~Pa}$ に到達したと同時に $1 \mathrm{~K} / \mathrm{s}$ の速度で昇温を開始した。接合温度は $1073 \mathrm{~K}, 1123$ $\mathrm{K}$ 抢よび $1173 \mathrm{~K}$ の 3 条件で行い，各々の温度で $3.6 \mathrm{ks}$ 保持 した試料を作製した．降温は Ar ガスを導入し加圧冷却とし た、また，同材同士では組成が同じであるため，接合界面近 傍の拡散状態が判別できない，相互拡散分布を観察する目的 として, 一部の試料は $\mathrm{Cu}$ と全率固溶となる $\mathrm{Ni}$ を箔 $(10$ $\mu \mathrm{m})$ の状態でインサートして接合を行った。 なお，クロム酸 化皮膜の性質を詳細に知るために同様の酸化皮膜を有する SUS304 を無酸素銅と同条件に打いて拡散接合し，接合機構 の解明に対する参考とした。

得られた接合体は, 継手強度を測定するために引張試験片 が加工できるサイズに切り出し, 残りは接合界面の組織観察 用として使用した。引張試験はクロスヘッド速度 $1.67 \times$ $10^{-2} \mathrm{~mm} / \mathrm{s}$ で行い，接合界面で破断した試料に扮いては SEM (Scanning Electron Microscope)で破面を観察し, 介 在物が存在した場合は EDX (Energy Dispersive X-ray Spectrometry)により分析した。接合界面近傍の観察は, 電 解研磨を施して表面の凹凸をできるかぎり小さくした後に
SEM で行い, 結晶組織は EBSD (Electron Back Scatter Diffraction Pattern)を使用して撮影した。 また，ニッケル筞 をインサートした試料に掞いては, EDXによる元素マッピ ングから相互拡散の状態を確認した.

\section{3. 実 験 結 果}

前報4)で述べたが，クロム銅合金は $1073 \mathrm{~K}$ より急激に硬 度が低下し, $1173 \mathrm{~K}$ では析出硬化時の約 $1 / 2$ まで軟化す る.これに伴い, 酸化皮膜の破砕分散を目的とした加圧方式 では高温になるにつれバレリングが顕著に生じていた．本研 究の手法では, 最も高い接合温度 $1173 \mathrm{~K}$ で拡散接合を行っ た試料においても, マイクロメーターによる計測では寸法変 化が検出できないほど無变形に近い状態であった．プレス装 置などにより加圧はしないものの室温で試料を治具で固定す るため, 厳密に言うと温度上昇に伴う試料と治具との熱膨張 差により負荷がかかる。これについては, 試料と治具との間 に緩衝材を挿入して，熱膨張による負荷を緩和していること をはじめに言及しておく．

各々の温度により拡散接合を行った試料の継手強度を Fig. 1 に示す，図中に示される值は，各温度で 5 本作製した 内の最も強度が低かった引張試験片の值である．酸化皮膜の 破砕分散を試みた場合，接合温度 $1073 \mathrm{~K}$ ，接合圧力 $2 \mathrm{MPa}$ の条件では, 接合面の算術平均粗さ $R_{\mathrm{a}}$ を約 $0.4 \mu \mathrm{m}$ 以下に すると引張試験片の加工中に破断が生じたことを，これまで に著者は報告した ${ }^{4)}$ 。これに基づき接合温度を $1073 \mathrm{~K}$ 以上 と設定したが，本研究に用いた接合方法では，1073 K で接 合を行った場合においても良好な継手状態が得られた。二点 鎖線により示している母材強度は, 受入材に $1073 \mathrm{~K}$ で 3.6 $\mathrm{ks}$ の熱処理を施した 3 本の丸棒から得られた各々の引張強 度を平均した值であり, 約 $257 \mathrm{MPa}$ である. 温度上昇に伴 ってクロム銅合金の軟化が進むため, 伸びが増加し破断強度 が徐々に低くなっているものの, 接合界面における破断は起 きず，引張試験を行ったすべての試料が母材破断に至った.

Fig. 2 は, 接合温度 $1073 \mathrm{~K}$ および $1173 \mathrm{~K}$ で拡散接合を 行った試料に抢ける接合界面近傍の SEM 写真である. 黒矢 印で示す位置が接合界面であり, 機械研磨の際に材料の延伸

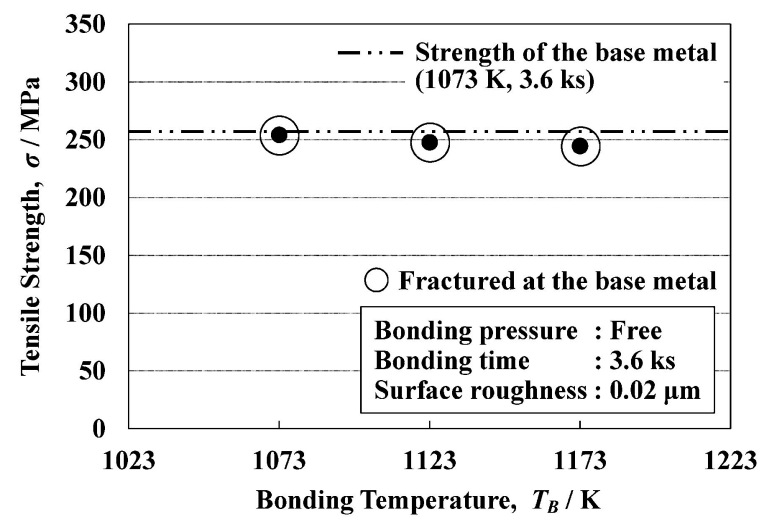

Fig. 1 Relationship between tensile strength and bonding temperature. The solid black circles surrounded by the circles indicate that the specimens were fractured at the base metal. 
によりボイドが埋まる可能性があるため，電解研磨を施した 上で撮影した．点在している白い介在物はクロムの析出物で ある. $1073 \mathrm{~K}$ で接合した試料には Fig. 2 (a)に示すように微 小なボイドがいくつか残存しており, さらに電解研磨を施し たことで接合界面に沿って部分的に窪みが生じた。本研究で は加圧をしていないため, 表面凹凸部の変形機構によるボイ ドの消失は起こらないに等しい。事前に接合面をできるかぎ り平滑にしているが，接合面の全領域を原子単位で近接させ ることは不可能である. 大橋らは, ボイド半径が $2 \mu \mathrm{m}$ 以下 であれば拡散機構によるボイドの収縮が加速すると報告して おり6)， $R_{\mathrm{a}}: 0.02 \mu \mathrm{m}$ に仕上げている面同士であれば接触さ せた段階でこのサイズを下回っている．したがって，接合時 間を延長すれば，これらのボイドは消失に向かうことが予想 される. 一方, Fig. 2(b)に示すように接合温度が $1173 \mathrm{~K}$ の 場合には，本研究で用いた SEM の分解能では明確に判別で きるボイドや窪みは観察されず，接合界面の特定も困難であ った。しかしながら，1073 K および $1173 \mathrm{~K}$ で接合した試
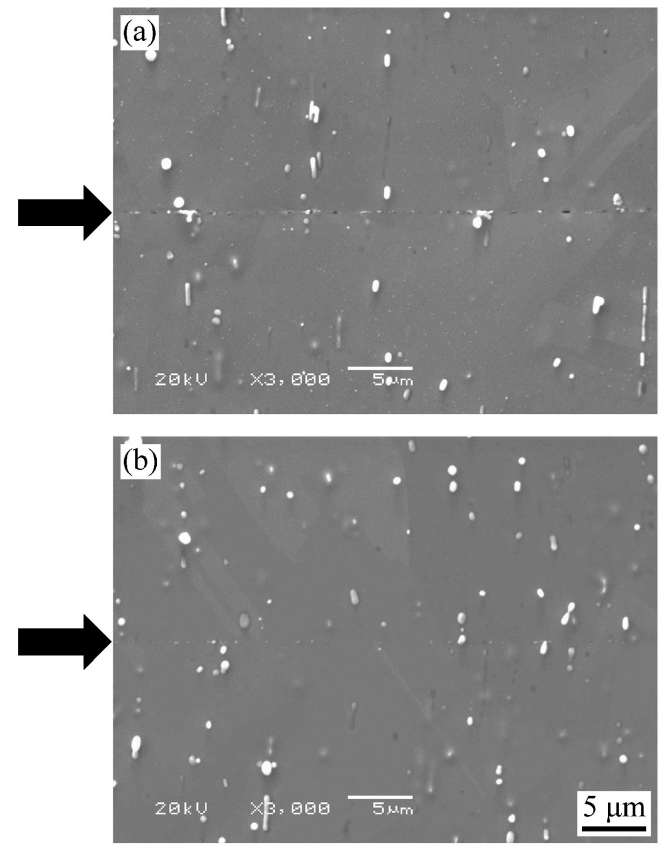

Fig. 2 Bonded interfaces of the specimens fabricated at (a) $1073 \mathrm{~K}$ and (b) $1173 \mathrm{~K}$. The black arrows indicate the bonded interfaces.
料ともに，母材内に存在しているクロムの析出物と比較する と非常に小さいが，それらの析出物とは性質が異なると思わ れる介在物が接合界面に沿って直線的に点在していた.

同材接合の場合，当然のことながら相互拡散の有無は確認 できない，そこで $\mathrm{Cu}$ と全率固溶する $\mathrm{Ni}$ をインサートして 拡散接合を行い，各々の接合温度で接合した試料の接合界面 近傍に抢ける拡散分布を観察した。インサート材には厚さ $10 \mu \mathrm{m}$ のニッケル箔を用いた．その元素マッピングを Fig. 3 に示す．点線が示す位置がクロム銅合金とニッケル䇴の接合 界面である.アレニウス型の式 $D=D_{0} \exp (-Q / R T)$ より各 々の温度に打ける拡散係数 $(D)$ を求め, $x^{2}=2 D t$ に代入して $\mathrm{Cu}$ 中に打ける $\mathrm{Ni}$ の拡散距離を算出すると，接合温度 1073 $\mathrm{K}$ では $2.5 \mu \mathrm{m}, 1173 \mathrm{~K}$ の場合は $7.2 \mu \mathrm{m}$ である。両温度で 接合した試料とも，クロム銅合金中に拡散した Ni の拡散距 離が算出した值とほぼ合致しており，対象面間で金属結合が なされていると考えられる.

Fig. 4 に SEM-EBSD により撮影した接合界面近傍の IPF (Inverse Pole Figure) map を示す。（a）が接合温度 1073 K，（b）が $1173 \mathrm{~K}$ で拡散接合を行った試料であり，高角粒
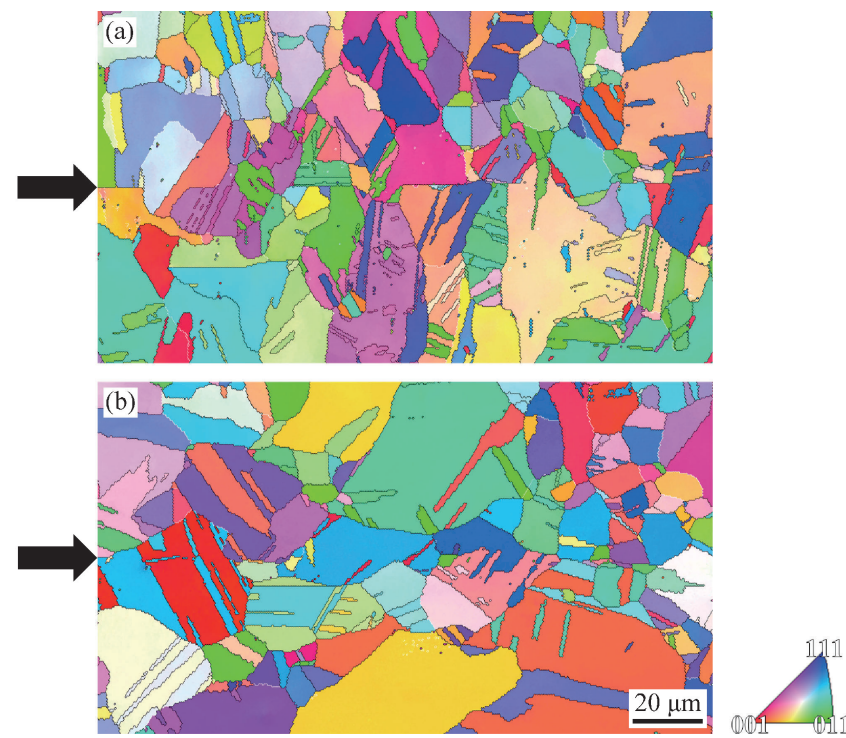

Fig. 4 Microstructures near the bonded interfaces of the specimens fabricated at (a) $1073 \mathrm{~K}$ and (b) $1173 \mathrm{~K}$. The black arrows indicate the bonded interfaces. The images were taken by means of SEM-EBSD.
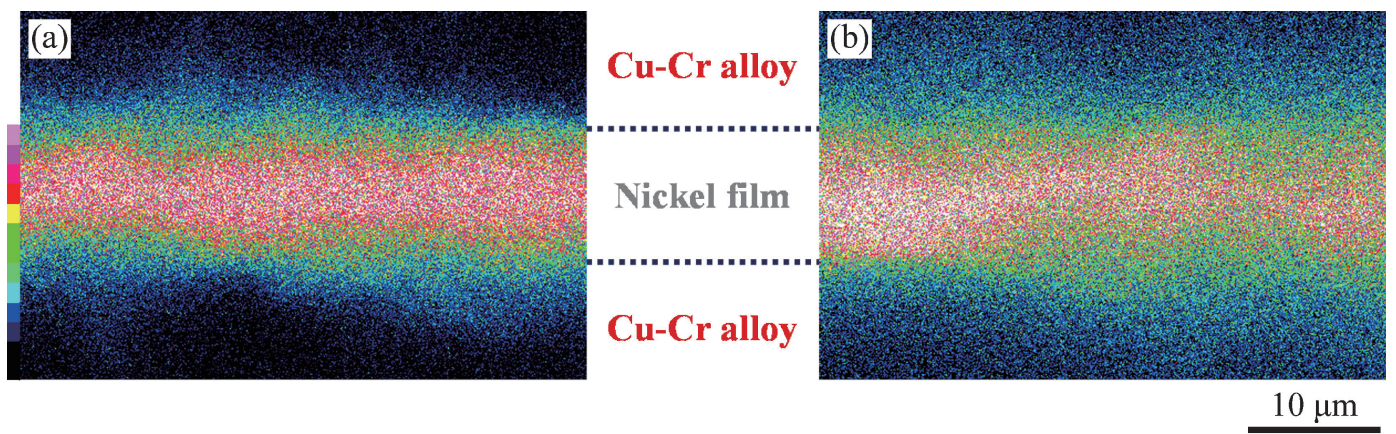

Fig. 3 Element maps with $\mathrm{Ni}-\mathrm{K} \alpha$ near the bonded interfaces in the specimens fabricated at (a) $1073 \mathrm{~K}$ and (b) $1173 \mathrm{~K}$ by inserting a nickel film. The dashed lines indicate the bonded interfaces between chromium-copper alloy and nickel film. 
界を黒線，低角粒界を白線で区別して示している。黒矢印は 接合界面の位置を図示している。なお，ステップサイズは $0.5 \mu \mathrm{m}$ で, 撮影面積に対して析出しているクロムの大きさ が非常に小さいため, Phase は銅のみで撮影した，両温度で 接合を行った試料ともに再結晶化していたが， $1173 \mathrm{~K}$ で接 合した試料は $1073 \mathrm{~K}$ と比較して平均結晶粒径が大きく，結 晶粒が粗大化していた. 温度差による拡散速度の違いも要因 だと思われるが， $1173 \mathrm{~K}$ では微量であるが $\mathrm{Cu}$ 中に $\mathrm{Cr}$ を固 溶することができる，材料硬度の急激な低下を考慮すると， 析出していたクロムの減少によるピン止め効果の弱化も結晶 粒成長を促進させた理由の一つであると考えられる。

また，接合温度 $1073 \mathrm{~K}$ で拡散接合を行った試料には，接 合界面に沿って直線状に結晶粒界が形成されている部分が観 察された。 $1173 \mathrm{~K}$ に接合温度を上昇させた場合には，一方 の結晶粒が接合界面を越えて相手側へ侵入し，組織イメージ 上では接合界面の特定が非常に困難なほど，ほぼ全面におい て結晶粒界移動が進行していた. SEM-EBSDで結晶組織を 撮影しているため, 粒界移動に対する結晶方位差の影響も考 察が可能である。これまでに，接合界面部に形成される結晶 粒界が高角あるいは低角であるかにより空隙数が異なるが， 継手強度や破断形態には影響しないことが報告されてい る7).しかし, 本研究で撮影を試みた範囲では低角粒界を形 成している部分がなく, 方位差による考察は行わないことと する。

\section{4. 考察}

接合雾囲気がクロム酸化皮膜に及ぼす影響を明らかにする ため, 接合面の面粗度を $R_{\mathrm{a}}$ : 約 $0.6 \mu \mathrm{m}$ で仕上げた後に化学 研磨を施した接合面同士を，昇温中は接触させずに雾囲気 $\left(4 \times 10^{-3} \mathrm{~Pa}\right)$ に露呈させておき，接合温度 $1073 \mathrm{~K}$ に到達し たと同時に接合圧力 $5 \mathrm{MPa}$ で加圧して接合時間 $3.6 \mathrm{ks}$ 保持 した。その試料に打ける破面を Fig. 5 に示す。酸化皮膜の 破砕分散に合わせた条件設定であるため対象物の变形は抑制 できず，この条件では試料にバレリングが生じることを述べ

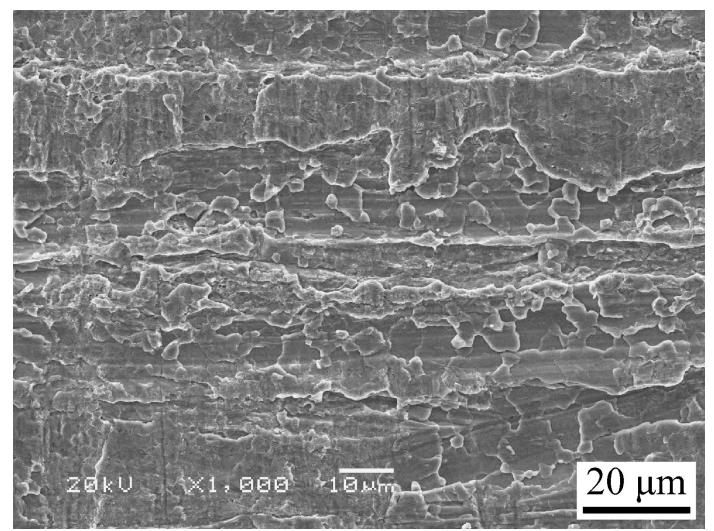

Fig. 5 Fractured surface after tensile test in the specimen bonded at $1073 \mathrm{~K}$ for $3.6 \mathrm{ks}$ with a pressure of $5 \mathrm{MPa}$. The whole bonding surface of the specimen was exposed in a degree of vacuum of $4 \times 10^{-3} \mathrm{~Pa}$ until temperature was raised up to bonding condition.
ておく．表面にあった凹凸部は加圧により潰されているにも かかわらず，互いに密着していた部分には延性破壊を示すデ ィンプルは観察されなかった，つまり，酸化皮膜を破砕する ぞころか金属結合に至った箇所もなかったと考えられる.

添加されているクロムは，不動態膜で知られるように酸化 物を形成しやすい金属である。これは大気中のみならず真空 中においても同様のことが言える. $2 \mathrm{Cr}+3 / 2 \mathrm{O}_{2} \rightarrow \mathrm{Cr}_{2} \mathrm{O}_{3}$ の 反応式に括けるギブズエネルギー变化は, 真空排気による減 圧環境を考慮すると $\Delta G=-1130000+273.9 T+8.314 T \ln$ $\left(P_{\mathrm{O}_{2}} / P^{\ominus}\right)^{-3 / 2}$ となる． $T$ は温度， $P_{\mathrm{O}_{2}}$ は酸素分圧であり，各 種物質の熱力学的数值は金属データブック（日本金属学会 編)の記載值を用いた。工業炉に使用される真空ポンプは DP(Diffusion Pump)が一般的で, 到達真空度は $10^{-3} \sim 10^{-4}$ $\mathrm{Pa}$ 程度である。大橋が質量分析器で測定した真空中におけ る酸素残留量 $0.5 \mathrm{Vol} \%$ を用いて計算した場合 ${ }^{8)}$ ，クロム銅 合金の融点以下で $\Delta G$ 值が正に転じることはなく，クロムの 酸化は防げないことを意味する。しかし，前述した現象が避 けられないとしてもクロムの析出物は Fig. 2 に示したよう に点在して抢り, 表面全体を覆っているわけではない。クロ ム酸化皮膜がたとえ強固になったとしても，この温度および 雲囲気であれば銅酸化物は分解反応が起きるため, 銅同土が 密着している部分で接合は達成されるはずである. Fig. 5 の ように破面にディンプルが観察されないというのは不自然で あり，金属結合を阻害する要因が別にあることを示唆してい る.

上記要因を明らかにするため, 電解研磨した試料に真空中 $\left(4 \times 10^{-3} \mathrm{~Pa}\right)$ で $1073 \mathrm{~K}, 3.6 \mathrm{ks}$ の熱処理を実施した。試料 の表面に抢ける SEM 写真および元素マッピング $(\mathrm{Cr}-\mathrm{K} \alpha$, O-K $\alpha)$ を Fig. 6 に，そのスペクトルを Fig. 7 にそれぞれ示 す. 析出物の大きさが EDX 分解能の限界に近いため検出 ピークは弱いが，Fig. 6(a)ならびに Fig. 6(b)より銅のみが 電解研磨により取り除かれ，クロムの析出物が突出している のが明白に観察される，また，ピークこそ検出できなかった が，析出したクロムが存在している部分で酸素の検出度合い が周囲よりも少し強いことが Fig. 6(c)の元素マッピングに より分かる. 電解研磨から分析に移行するまで十数分であっ たが，その間に析出物の表面にはクロム酸化皮膜が生成され たと解釈できる．この試料を前述した条件で熱処理すると， 試料に着色が生じ, 表面は Fig. 6(d)に示すような所々に窪 みが生じた状態になる。これを元素分析すると，窪んでいな い部分で $\mathrm{Cr}$ 抢よび $\mathrm{O}$ が検出された. Fig. 7 に示すようにス ペクトルにおいても $\mathrm{Cr}$ のピークが大幅に強くなり, 熱処理

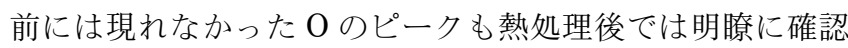
することができる，注目すべきは，処理前にクロムが析出し ていなかった部分にもクロムの酸化物が生成している点であ る、鈴木らは，低酸素分圧下で銅合金を焼鈍した際，酸化し やすい元素が表層に濃化し，その下側に欠乏層が形成される ことを報告している ${ }^{9)}$ をた，Koyatsu らは，クロム銅合金 を $673 \mathrm{~K}$ で $24 \mathrm{~h}$ のベークアウトを行うとクロムがバルクか ら表面に移動することを述べている10)。つまり，クロム銅 合金は加熱すると表面がクロムで濃化し，続けて真空中であ っても濃化したクロムが微量酸素と反応することで，表面の 

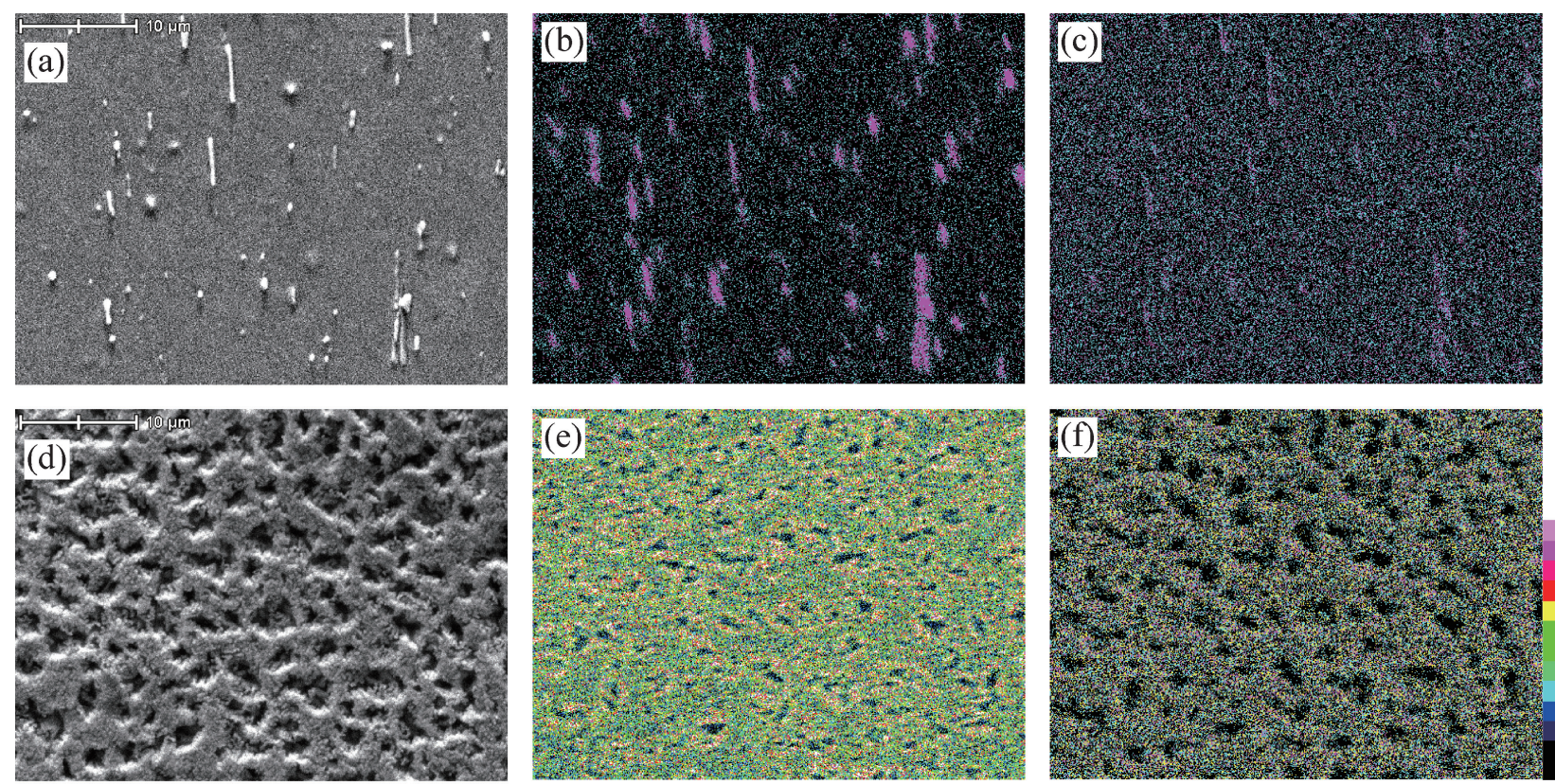

$10 \mu \mathrm{m}$

Fig. 6 SEM photographs and element maps of the surface of chromium-copper alloy (a) $\sim$ (c) before and (d) $\sim(\mathrm{f})$ after annealing at $1073 \mathrm{~K}$ for $3.6 \mathrm{ks}$ in a degree of vacuum of $4 \times 10^{-3} \mathrm{~Pa}$. The images (b) and (e) are the element maps with $\mathrm{Cr}-\mathrm{K} \alpha$, the images (c) and (f) are those with $\mathrm{O}-\mathrm{K} \alpha$.

(a)

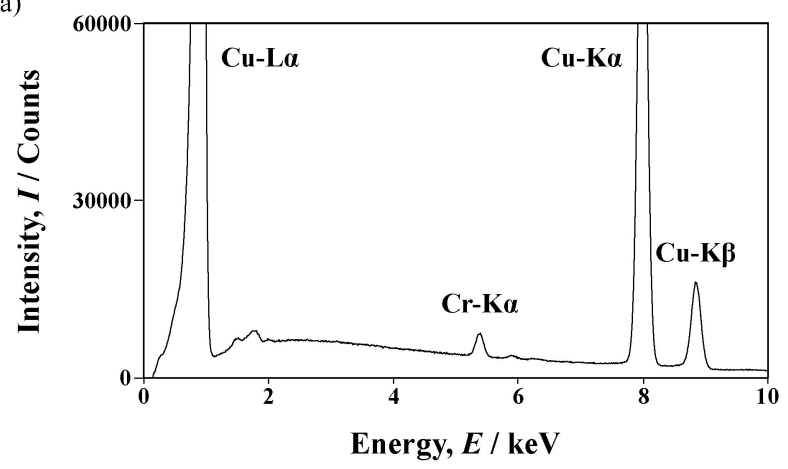

(b)

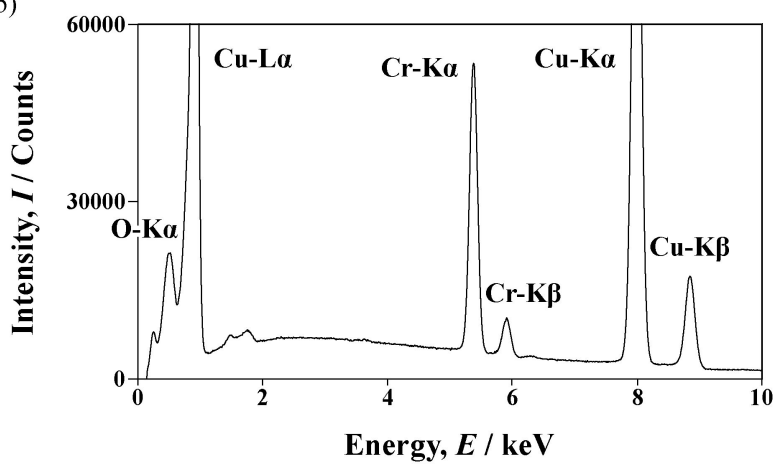

Fig. 7 EDX spectrums of the surface shown by Fig. 6 . The images (a) and (b) are the spectrums of the specimens before and after heat treatment, respectively.

ほぼ全域に強固なクロム酸化皮膜を形成すると考えられる. $\mathrm{Cu}$ 中の $\mathrm{Cr}$ は拡散速度が比較的速く，酸化皮膜を形成させ ないためには，いかに迅速に接合面を外部と遮断させるかが 重要となる.

2.で述べたが，本研究の接合方法では可能なかぎり接合
面を平滑に仕上げている. 目的は対象物の変形抑制に際して 圧力を負荷させないため, 事前に接合面同士の密着面積を増 加させなければならないからである. その一方で, この表面 粗さの調整は, もう一つの重要な役割を果たしている。も し, 前述したクロム酸化皮膜の形成が起こっていれば Fig. 1 〜4 に示したような結果には到底至っていないはずである. 前報では昇温前から圧力を負荷して拡散接合を行っても, 接 合面の表面粗さが細かくなると接合ができなくなることを報 告した4). 理由として, 粗さが細かくなるにつれ表面の凸部 が小さくなる上に, 応力分散が起きることで凸部の変形量が 減少する.したがって, 酸化皮膜が破砕しにくくなり, 新生 面同土が接触できないためだと論じた。けれども，エメリー 紙\# $4000\left(R_{\mathrm{a}}: 0.18 \mu \mathrm{m}\right)$ で接合面を調整した状態の試料まで しか調べておらず，これより平滑な場合に変化が起こらない とは断定できなかった．クロム銅合金は，クロムを添加する ことで高温時における機械的強度を高めた合金である。つま り，軟化するまでは接合面の凹凸部が形状を維持し，雲囲気 中の微量酸素が接合面間の隙間に侵入してしまうと換言する ことができる. 以上から, 本研究において仕上げた面が外部 から酸素の侵入を防止するシール性を保有していたことが， 継手強度の大幅な向上をもたらした一つの要因と言える.

接合中に新たに強固な酸化皮膜が生成することを未然に防 ぐことは上述した方法で解決できる. しかしながら, 最初か ら表出している析出物の周囲に既存するクロム酸化皮膜は残 存したままである，マクロ的に見ると，接合面をクロムの析 出物が占有する率は比較的大きく, 同時にクロム酸化皮膜の 占有率も大きいということである. 事前に除去したとしても 大気中を通さずに清浄化工程から接合工程へ移行させること は非常に難しい，接合中に抢いて，その対策を講じなければ 
ならないのは必然となる．酸化皮膜の消失機構は母材への酸 素拡散, 酸化物の分解, カーボンや不純物による還元など, これまでにいくつか提示されている11).クロム銅合金の場 合, 熱力学から考えるとクロムよりも酸素との親和力が強い 不純物による還元以外に可能性はない．ただ，還元できる不 純物が含有していたとしても，継手強度の改善に繋がるほど の影響を与えているとは推測しがたい。

クロムの析出物を覆う酸化皮膜では挙動の確認がしゔらい ため, クロム銅合金と同様の酸化皮膜を有するオーステナイ 卜系ステンレス鋼 SUS304 と無酸素銅を拡散接合して観察 を試みた. 引張試験により接合界面で破断した試料の無酸素 銅側の破面における SEM 写真を Fig. 8 に示す．接合は，意 図的に接合界面で破断させるために接合面の表面を粗くして 面同士の密着面積を低減し, 接合圧力 $1 \mathrm{MPa}$ で加圧した状 態において接合温度 $1173 \mathrm{~K}$ まで昇温させて接合時間 $3.6 \mathrm{ks}$ 保持する条件にて行った．破面には大きさの異なったディン プルが混在しているが，大きなディンプルの底には矢印で示 すような介在物が観察される。この介在物を EDXにより分 析した結果をFig. 9 に示す。母材が無酸素銅であるため $\mathrm{Cu}$

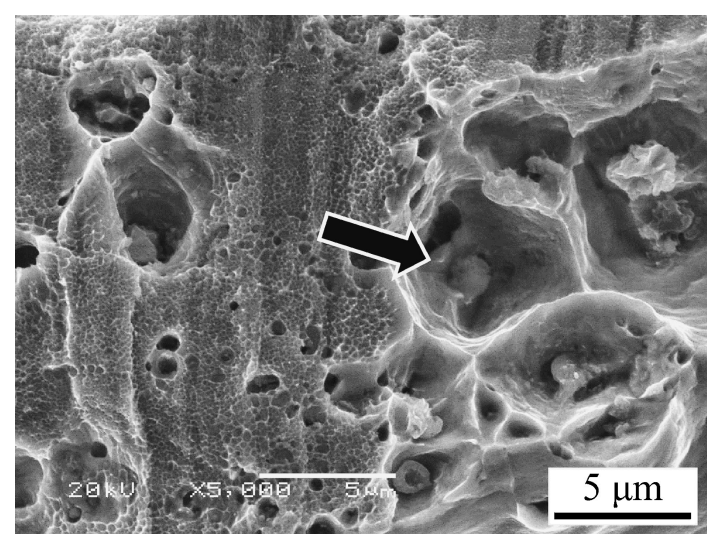

Fig. 8 Inclusions at the bottom of dimples formed by fracture at the bonded interface between oxygen free copper and stainless steel. This is the fractured surface of oxygen free copper side in the specimen fabricated at $1173 \mathrm{~K}$ under $1 \mathrm{MPa}$ for $3.6 \mathrm{ks}$.

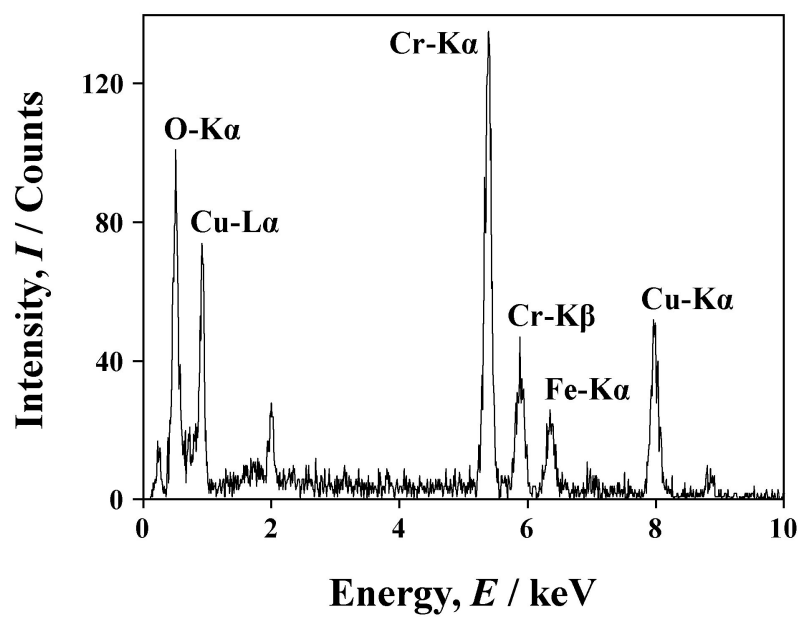

Fig. 9 EDX spectrum of the inclusion indicated by the black arrow in Fig. 8.
のピークが主として検出されるはずだが, 介在物からは $\mathrm{Cr}$

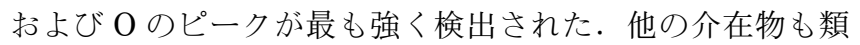
似したピークを示していた．無酸素銅中にクロムは存在しな いため, これらの介在物はSUS304の表面を覆っていたク ロム酸化皮膜が凝集してできたものと考えられる．ステンレ 又鋼を覆うクロム酸化皮膜は，不動態で知られているように 破壊されても自己修復する。しかし，凝集挙動が生じれば酸 化皮膜が不在となった部分で金属結合がなされ，この異材接 合でも接合条件次第では継手部が無酸素銅の母材強度を上回 ることを確認している．したがって，クロム銅合金上の析出 物を覆う酸化皮膜にも同じことが言えるはずであり，酸化皮 膜が凝集することによって接合面間の金属結合を助成し，

Fig. 1 で示したように母材破断に至るほどの継手強度を得る ことができたと結論付けられる.

酸化皮膜の凝集により新生面が表出できる可能性は確かに 増加するが，酸化物そのものが消失するわけではない。これ らの凝集物は，元接合界面であった部分に残留し続けること になる．普通に考えれば凝集物がある以上，接合がなされた 断面積が母材部を超えるはずはなく, 引張試験の際に凝集物 が起点となって破断が起きても不自然ではない，大橋らは， 試験片形状を不均一にすると多軸性の応力が発生することに より，引張試験では一軸方向の強度が増大すると指摘してい る ${ }^{12)}$ 。一面に沿って凝集物が存在しているということは, 凝集物が周囲と結合していないと考えると，元接合界面であ った部分は多孔性を持っていると見なせる，つまり，接合界 面に対して垂直な方向に抢ける強度は母材を上回る結果に至 ったが，平行な方向に負荷をかけた場合には，良好な結果が 得られない可能性があることは否定できない.

その一方で, 継手強度測定では全試料が母材で破断したた め比較はできないが，Fig. 2〜4を見ると接合温度により接 合界面状態に差が生じていることが明確である。1073 K で 接合を行った場合には，数は極めて少ないが接合界面に微小 なボイドが残存し，模糊ではあるが界面に沿った窪みが部分 的に見受けられる。橋本らは，この接合界面に生じる窪みを Groove と表現している13). Groove は界面に沿ってできる結 晶粒界のエネルギーが母材中の粒界よりも非常に高く, 加え て局部的に異なったエネルギーを持っているために発生する と推察している．また，接合界面をなたがり結晶粒界が移動 するためには，各々のエネルギーが等しくなければならない と論じている. Fig. 4(a)において粒界が界面から離れず固 着している箇所を SEM 写真で見ると窪みが生じており，橋 本らが報告した内容と合致している，また，桃野らは，酸化 物や不純物が接合界面の粒界移動に大きな影響を及ぼすこと を述べている ${ }^{14)}$ 。しかし，酸化物と銅との界面エネルギー は, 銅同士の界面エネルギーよりも低いため, 橋本らの報告 とは矛盾が生じる. 本研究結果においても, 各接合温度で拡 散接合を行ったすべての試料で，接合界面部にあった結晶粒 界が移動したことにより消失している場合でも，凝集したク ロム酸化物は残留したままである，この結果から，接合界面 をまたがる結晶粒界移動を妨げているのは，ボイドのような 空隙を含めた不完全な金属結合部が存在するためであると考 えられる。 
拡散接合に打ける結晶粒界移動による接合界面の消失と継 手強度の関係は, 未だに不明な点が多い。言及できない理由 は, 接合界面の消失現象が起きていなくとも継手強度が得ら れる点にあり, 本研究結果も一部の試料がそうである。た だ，一般的に考えると接合界面が組織的に消失した継手部が 信頼性は高いと判断されるのは言うまでもない。接合対象と なる面同士の密着と清浄化がなされていれば，拡散接合は接 合温度および接合時間に律則される. 前者の方が拡散に与え る効果は大きいが，クロム銅合金の場合は，温度の上昇とと もにクロム酸化物による着色やクロムの蒸発が懸念される. また，高温によるクロム銅合金の機械的性質の低下は，723 $\mathrm{K}$ で $10 \mathrm{ks}$ の時効処理を施すことで回復するが15)，コストや 効率を考慮すると賢明ではない。そのため，クロム酸化皮膜 が凝集挙動を示すことのできる最低温度ならびに必要保持時 間の定量化を試みることが望まれる。これについては次報に て報告する。

\section{5. 結言}

クロム銅合金の拡散接合において，真空中におけるクロム 酸化皮膜の特性ならびに挙動を明らかにしたことで, 被対象 物を変形させることなく母材破断を達成する継手状態を得る ことができた。本研究結果をまとめると次のと抢りである.

(1) 接合面が雲囲気に曝されている場合, 加熱によりクロ ムが表面で濃化し，さらに低酸素分圧下においても酸化が進 行するため, 全面に強固なクロム酸化皮膜が生成される.

（2）接合面を表面粗さ $R_{\mathrm{a}}: 0.02 \mu \mathrm{m}$ 程度まで調整した試 料ではシール性が向上し，(1)に述べた雾囲気の影響をほとん ど受けなくなる。同時に接合面同士の密着も事前に得られる ため加圧が不要であり, 対象物を変形させることなく拡散接 合を達成することができる.

（3）クロムの析出物を覆う酸化皮膜は大気中で容易に形成 するが，高温にすることで凝集挙動を示す．接合温度 1073 $\mathrm{K}$ 以上で拡散接合を行った試料においては，接合界面では
なく母材部で破断が生じる。また，ニッケル䈃をインサート した際の各元素の相互拡散距離もアレニウス型の式で求めた 理論值とほぼ近似する。以上より，クロム酸化皮膜が凝集す る温度領域は $1073 \mathrm{~K}$ 未満であることが示された。

(4) 接合温度 $1173 \mathrm{~K}$ では接合界面が結晶粒界移動により 消失するが，1073 K の場合には界面に相当する部分で直線 的な粒界が所々に観察される。一方，酸化皮膜が凝集した酸 化物は, 粒界移動の有無に限らず接合界面に残存したままで ある、このことから，粒界を接合界面に固着させる原因が酸 化物などの介在物よりもボイドの影響が大きいことが示唆さ れる。

\section{文献}

1) H. Takegami and T. Shinoda: Quarterly Journal of JWS 22 (2004) 477-483.

2) M. Tsukamoto, S. Sakamoto and A. Yamamoto: J. Japan Inst. Metals 75(2011) 592-599.

3) M. Tsukamoto and A. Yamamoto: J. Japan Inst. Metals $\mathbf{7 6}$ (2012) 338-344.

4) M. Tsukamoto, T. Kajiura and A. Yamamoto: J. Japan Inst. Metals 76(2012) 521-527.

5) O. Ohashi, K. Tanuma and T. Kimura: Quarterly Journal of JWS 4 (1986) 53-59.

6) O. Ohashi and T. Hashimoto: Journal of JWS 45(1976) 485491.

7) O. Ohashi, T. Yoshioka, I. Nitta and N. Furuta: Quarterly Journal of JWS 18(2000) 324-330.

8) O. Ohashi: Quarterly Journal of JWS 4 (1986) 514-520.

9) S. Suzuki, T. Kimura, M. Eto, M. Mori and M. Okubo: Journal of the Japan Copper and Brass Research Association 44 (2005) 210-213.

10) Y. Koyatsu, H. Miki and F. Watanabe: Vacuum 47 (1996) 709711.

11) O. Ohashi, K. Tanuma and K. Yoshihara: Quarterly Journal of JWS 3(1985) 477-483.

12) O. Ohashi and T. Hashimoto: Journal of JWS 46(1977) 9971003.

13) T. Hashimoto and K. Tanuma: Journal of JWS 38(1969) 12251233.

14) T. Momono and K. Ikawa: J. Japan Inst. Metals 42 (1978) 211217.

15) T. Omae, Y. Fukaya, S. Hirai and S. Inoue: Preprints of the National Meeting of JWS 32(1983) 96-97. 